\title{
Cytological and Morphological Studies on the Gametophytes of Ferns VII
}

\author{
The Vital Staining of Fern-prothallium and the Influence of \\ Hydrogen Ion Concentration on it*
}

\author{
By Isami IGURA**
}

\begin{abstract}
伊倉伊三美：羊㐘類の配偶体に関する細胞学的並に形態学的研究 VII 羊歯類前葉体の生体染色と水素イオン濃度の影響
\end{abstract}

Received August 12, 1954

\section{Introduction}

A considerable number of researches had been carried out on the vital (intravital) staining in plant cells. After the initial report on the reaction of aniline dyes to the living cells by Pfeffer (1886), the reactions of the vital staning were investigated by Champbell (1887) on the cell of staminal hair of Tradescantia, by Yamaha and Sawai (1943) on the tissue cell of tomato-fruit, by Yamaha and Ueda (1946) on Oscillatoria princeps, by Yamaha (1946) on Spirogyra, the root-hair of Hydrocharis, by Bhargava (1950) on the vacuome of Saprolegniaceae, and recently by Höfler and Schindler (1953) on various Closterium-species.

However, as to the vital staining on fern-prothallia Klebs (1919) reported on the staining of the living prothallia in Pteris longifolia and Ceratopteris thalictroides, using aniline colors. In the course of the works on the cell-physiological analysis of growth and morphogenesis in fern-prothallia, Reuter (1953) lately studied on the vital staining of the prothallia in Dryopteris parasitica, applying neutral red. But both authors discribed scarcely in the results of the vital staining on the cellular elements in the prothallia, or on the spermatozoids. Therefore, the writer attempted to make clear in detail the staining properties of cellular elements of the fernprothallium or of the spermatozoids in vivo, applying many different dyes. The influence of the hydrogen ion concentration upon the vital staining of the cells of the prothallium is also investigated.

Concerning the vital staining of the spermatozoid other than Pteridophyta was reported by Champbell (1887, '88) or Waldner (1893), and then that of the fernspermatozoid was studied by Yuasa (1937). With respect to the investigations on

* 1) A part of the present study was delivered at the 18th annual meeting of the Botanical Society of Japan, October, 1953 at Kanazawa University, Kanazawa City. 2) The expenditures of this research were paid in part by the Grant in Aid for the Scintific Research from the Ministry of Education

** Biological Institute, Faculty of Education, Yamagata University. Yamagata City, Japan 山形大学教育学部生物学教室 
the staining of the living spermatozoids the writer has published already in preceding paper (Igura 1954a), so they will not be repeated here.

\section{Materials and Methods}

The prothallia cultured in the writer's laboratory were used. They belong to Polypodiaceae or Plagiogyriaceae, and are following eleven species:

Asplenium Sarelii Hooker, Asplenium Trichomanes Linnaeus, Athyrium multifidum Rosenstock var. deltoideum Nakai, Ctenitis quelpaertensis H. Ito, Dryopteris cystolepidota C. Christensen, Dryopteris saxifraga H. Ito, Pentarhizidium japonicum Hayata, Plagiogyria Matsumureana Makino, Pteridium aquilinum Kuhn var. latiusculum Tagawa, Rumohra mutica Ching, Thelypteris palustris Schott.

As staining dyes, the basic and the acid ones of thirty-three kinds which belong to monoazo, diazo, triphenylmethan, azin, oxazin, thiazin, or xanthin groups were used, and these dyes were applied also in the preceding work.

The solutions of various grades of the hydrogen ion concentration were prepared with the following mixed solutions: (1) $0.1 \mathrm{~N} \mathrm{HCl}$ and $0.1 \mathrm{~N} \mathrm{NaOH}$ or $0.1 \mathrm{~N} \mathrm{NH}_{4} \mathrm{OH}$, (2) Citrate-buffer-solution $(0.1 \mathrm{~mol}$. citric acid and $0.2 \mathrm{~mol}$. disodium hydrogen phosphate), (3) Acetate-buffer-solution ( $0.1 \mathrm{~N}$ acetic acid and $0.1 \mathrm{~N}$ sodium acetate), (4) Phosphate-buffer-solution ( $0.1 \mathrm{~N}$ potassium hydrogen phosphate and $0.1 \mathrm{~N}$ disodium hydrogen phosphate).

The dyes were dissolved in the redistilled water in concentration of 0.5-0.002 per cent. Each prothallium was immersed in each hard watch-glass, which contained 1 cc. of dye solution. The materials were kept in it for about from ten to thirty minutes, sometimes for about one hour, two hours, or twenty-four hours. Besides this treatment, one drop of the dye solution was put on the slide glass, in which the prothallia were steeped and left for the durations mentioned above. Then they were observed under the ordinary light microscope or the phase contrast microscope.

The vitality of the stained cells was determined by observing the plasmolysis and as the plasmolyticum $0.5 \mathrm{~mol}$. potassium chloride or $0.5 \mathrm{~mol}$. calcium chloride was applied.

\section{Experimental Results}

(A) The vital staining of the dye solution dissolved in the redistilled water.

(1) Athyrium multifidum Rosenstock var. deltoideum Nakai.

Dahlia violet $(0.002 \%, 20$ mins.); This solution stained the cytoplasm and membrane of the rhizoid or the spermatids in reddish violet (the young spermatid seemed not to be stained). To examined the days in which the prothallia can live, they were dipped in $0.002 \%$ dye solution and it was found that after seven days the prothallial cells showed no plasmolyses in the plasmolyticum. Therefore they hardly could survive more than seven days. After the death the nucleus, the membrane, 
the cytoplasm, and the plastid appeared to be colored, especially in the protonema cell.

The plasmolyses forms of the prothallial cells were generally convex in $0.5 \mathrm{~mol}$. $\mathrm{KCl}$-(Fig. 1, a) and almost concave in 0.5 mol. $\mathrm{CaCl}_{2}$-solution (Fig. I, b).

(2) Ctenitis quelpaertensis H. Ito.

Chrysoidin extra pure $(0.002 \%, 45$ mins.); The prothallial cell membrane was colored in faint yellowish orange, and the cytoplasm and membrane of the rhizoid and the spermatids were also stained. Janus green $(0.5 \%, 30 \mathrm{mins}$ ) ; The cytoplasm and membrane of the rhizoid and the caps of the glandular hairs (papillae) were colored in reddish violet. Neutral red $(0.002 \%, 30$ mins.); In this solution the special fact was observed. Dipping the prothallia in $0.5 \mathrm{~mol}$. solution for about six hours, the plstids in the prothallial cells gathered around the nucleus and these phenomena are to be called "Systrophe" reported in another plants by Germ (1932, '33) (Fig. 2).

(3) Dryopteris cystolepidota C. Christensen.

Eosin $(0.01 \%, 30$ mins.); The cytoplasm and membrane of the rhizoid and the spermatids were colored weakly in red or not. When the glacial acetic acid was added to this solution, the grade of staining was intensified and the prothallial cell membrane and the spermatid seemed to be stained. In the cytoplasm of the rhizoid the granular staining was observed. Methylene blue $(0.05 \%, 30 \mathrm{mins}$.); The cytoplasum and membrane of the rhizoid, the caps of the glandular hairs, and the spermatids were colored in light bluish violet. In the cytoplasm of the rhizoid appeared the vacuolar demixing mainly in 0.5 mol. KCl-solution (Figs. $3 \mathrm{a}, \mathrm{b}$ ), and the condenced cytoplasm generally in $0.5 \mathrm{~mol} . \mathrm{CaCl}_{2}$-solution (Figs. $4 \mathrm{a}, \mathrm{b}$ ). These facts may be supposed to be K- and Ca-type of the plasmolysis reported by Sakamura and Kanamori (1936). The diffused (homogeneous) and non homogeneous staning in the cytoplasm of the rhizoid were observed. Pyronin (0.02\%, 20 mins.); The prothallial cell membrane, the cytoplasm and membrane of the rhizoid, and the spermatids indicated the faint and light violescent red colors. The cytoplasm of the rhizoid showed the vacuolar demixing in $0.5 \mathrm{~mol}$. KCl-solution (Figs. $3 \mathrm{c}, \mathrm{d}, \mathrm{e}$ ). Neutral red $(0.02 \%, 0.002 \%, 20$ mins.); These solutions stained the cytoplasm and membrane of the rhizoid in reddish. After steeping in $0.002 \%$ solution, the prothallia were immersed in $0.5 \mathrm{~mol}$. KClsolution for about ten minutes, and then the vacuolar demixing were recognized. Nile blue $(0.05 \%, 15$ mins.); This dye solution stained the cytoplam of the rhizoid in bluish.

In all cases the plasmolyses of the prothallial cells occurred with $0.5 \mathrm{~mol}$. $\mathrm{KCl}$ or. $0.5 \mathrm{~mol}$. $\mathrm{CaCl}_{2}$-solution.

(4) Pentarhizidium japonicum Hayata.

Erythrosin $(0.01 \%, 20 \mathrm{mins}, 2 \mathrm{hs}$ ); While the cytoplasm and membrane of the rhizoid were stained very slightly reddish or not, just the same staining was found also in the spermatids in the antheridium. In the rhizoidal cell the cytoplasm were colored more deeply in the apical part than the other one of it. This phenomenon 
is considered as the polar staining (the polarity of staining) (Fig. 5). The neck canal cell and the ventral canal cell of archegonium are also observed to be stained. The cytoplasm, the nucleus, the membrane, and the plastids of the prothallial cell were all not colored. Magdara red (0.02\%, 20 mins, $2 \mathrm{hs}$.); The cytoplasm of the rhizoid and the caps of the glandular hairs were stained in violescent red and the former showed the granular staining (Fig. 6). Victoria violet $(0.01 \%, 20 \mathrm{mins}, 2 \mathrm{hs}$.); The cytoplasm of the rhizoid soon showed a reddish violet coloration and also the polarity of staining. Its membrane was very faintly colored.

Applying $0.5 \mathrm{~mol} . \mathrm{KCl}$ - or $0.5 \mathrm{~mol}$. $\mathrm{CaCl}_{2}$-solution, the plasmolyses of the prothallial cells were observed in every case.

(5) Pleridium aquilinum Kuhn var. latiusculum Tagawa.

Fuchsin red $(0.005 \%, 10$ mins.); The cytoplasm and membrane of the rhizoid were soon colored in violescent red. The spermatid (spermatid cytoplasm) in the antheridium was also stained. Although the staining of the cytoplasm of the rhizoid was generally homogeneous, some of the rhizoid rapidly showed the non homogeneous staining, as Reuter (1953) found in Dryopteris parasitica (Fig. 7). After three hours staining, when the prothallia were steeped in $0.5 \mathrm{~mol}$. $\mathrm{KCl}$-solution for about fifteen minutes, the plasmolyses occurred in the prothallial cells and in the cytoplasm of some rhizoids the vacuolar demixings were recognized and some presented the polarities of staining, where the apical portion was somewhat deeply colored. Methyl orange $(0.01 \%, 30$ mins.); The vital staining could not be observed in all structural elements of the prothallia or exceptionally the cytoplasm and the membrane were very weakly stained. Orange G $(0.01 \%, 30$ mins.); The vital staining did not occur in all structural elements. Thionin $(0.05 \%, 10$ mins.), Toluidin blue $(0.025 \%, 10$ mins.); Both dyes broght the almost same results. These results of the vital staining were good and fair positive effects. The membrane (and perhaps the cytoplasm also) of the prothallial cell was colored mainly in the median portion as seen in Fig. 10 a. Is it possible to consider this fact as a polar staining? As shown in Figs. $10 \mathrm{~b}, \mathrm{c}$, the staining was disturbed in $\mathrm{pH}$-solution and this phenomenon will be explained in the next report (Igura 1954c). The cytoplasm and membrane of the rhizoid were colored in diffuse or nonhomogeneous state. The spermatids found in- or outside of the antheridia and the caps of the glandular hairs were stained, too. The granular staining is produced occasionally in the cytoplasm of the rhizoid. The neck canal cell, the ventral canal cell, and the egg cell of the archegonium seemed to be colored.

(6) Rumohra mutica Ching.

Acid fuchsin $(0.01 \%, 15$ mins.); No element of the prothallia was stained in vivo, though in this experiment the prothallia were observed to be able to maintain their vital states for a long time. They were alive for about sixty-five days in this dye solution and after the death of the cell the nucleus, the membrane, the cytoplasm, or the plastid were stained, especially in the protonema cell as the example of dahlia violet stated above. Aniline blue (0.01\%, 30 mins.); The spermatid only showed 
very weak colors. Bismarck brown $(0.002 \%, 30 \mathrm{mins}$ ) ; The membrane of prothallial cell and the spermatids were slightly colored in brownish orange. So were also the cytoplasm and menbrane of the rhizoid, or the caps of the glandular hairs. Brilliant cresyl blue $(0.003 \%, 1 \mathrm{~h}$.$) ; The cytoplasm and membrane of the rhizoid, the caps of$ the glandular hairs, and the spermatids made slight and bluish colorations. Congo red $(0.005 \%, 20$ mins.); The elements above-mentioned were colored faintly in reddish orange. The plasmolyses of the prothallial cells arose in $0.5 \mathrm{~mol}$. KCl-solution and after about ten minutes the vacuolar demixing was found. The granular staining seems to be observed in some cases. Crystal violet $(0.0025 \%, 20 \mathrm{mins}$.); The results of the staining were good. The cytoplasm and membrane of the rhizoid, the spermatids which were in or out of the antheridia, the caps of the glandular hairs were stained in weak violescent colors. Fast green $(0.01 \%, 30$ mins.); The cytoplasm of the rhizoid, the spermatids, and the caps of the glandular hairs were colored in faint green. Indigo carmine $(0.01 \%, 1 \mathrm{~h}$.$) , Light green \mathrm{SF}(0.01 \%, 30 \mathrm{mins}$.$) , Methyl green$ $(0.01 \%, 1 \mathrm{~h}$.$) , Methyl red (0.01 \%, 20 \mathrm{mins})$; These four dye solutions did not stain all structural elements of the prothallium. Rhodamine B $(0.2 \%, 0.02 \%, 0.01 \%, 20$ mins.); The staining was effective. The membrane of the prothallial cell might be colored in slight violescent. The cytoplasm and membrane of the rhizoid, the spermatids in the antheridia, and the caps of the glandular hairs showed the same results. Safranin $(0.05 \%, 0.1 \%, 20$ mins.); The staining gave good results. The membrane of the prothallial cell, the cytoplasm and membrane of the rhizoid, and the spermatids were stained in red. Tropaeolin $000-1(0.005 \%, 30$ mins.); The prothallial cell membrane and the spermatids were colored in faint orange. Trypan blue $(0.1 \%, 20$ mins.); The spermatids only were stained in slight blue. In the cytoplasm of the rhizoid the vacuolar demixing was observed.

In the plasmolyticum of $0.5 \mathrm{~mol}$. $\mathrm{KCl}$ - or $0.5 \mathrm{~mol}$. $\mathrm{CaCl}_{2}$-solution the plasmolyses of the prothallial cells arose.

(7) Thelypteris palustris Schott.

Malachite green $(0.02 \%, 10$ mins.); This dye solution stained the cytoplasm of the rhizoid, the caps of the glandular hairs, and the spermatids in weak bluish green.

(8) Asplenium Sarelii Hooker, Dryopteris saxifraga H. Ito. Asplenium Trichomanes Linnaeus, Plagiogyria Matsumureana Makino.

Methyl violet $(0.005 \%, 10$ mins., 24 hs.); These four species were treated with this one dye solution. The cytoplasm and membrane of the rhizoid were colored in weak reddish violet and the caps of the glandular hairs (in Dryopteris saxifraga) (Fig. 8) and the spermatids (in Asplenium Sarelii and Plagiogyria Matsumureana) were also colored. The cytoplasm of some rhizoid showed the drop-like demixing in $0.5 \mathrm{~mol}$. $\mathrm{KCl}$-solution (immersed for thirty minutes), after staining with this dye solution (for about ten minutes) in Dryopteris saxifraga $\mathrm{H}$. Ito (Fig. 9).

(The present report will be continued by the following paper.) 


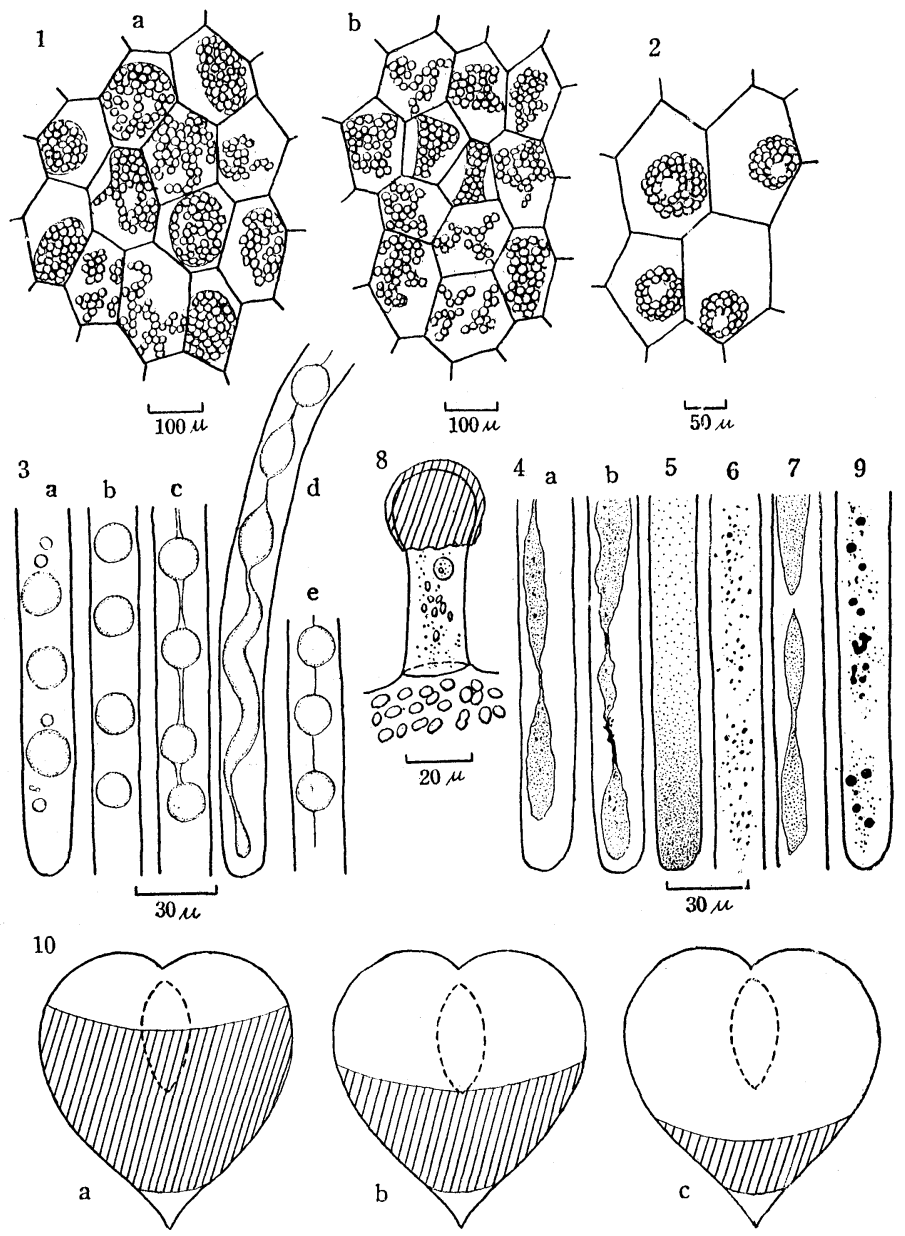

Figs. 1-10. The vital stainings and the phenomena accompanied by them in fern-prothallia,

1. The plasmolysis types of the prothallial cell in Athyrium multifidum Rosenstock var. deltoideum Nakai. a. Dipped in $0.5 \mathrm{~mol}$. KCl-solution ( $10 \mathrm{mins}$.), after stained by $0.002 \%$ dahlia violet. Convex type. b. Dipped in $0.5 \mathrm{~mol} \mathrm{CaCl}_{2}$-solution (10 mins.), after stained by $0.002 \%$ dahlia violet. Concave type.

2. "Systrophe" in the prothallial cell in Ctenitis quelpaertensis H. Ito. Dipped in $0.5 \mathrm{~mol}$. $\mathrm{KCl}$-solution ( $6 \mathrm{hrs}$ ), after stained by $0.002 \%$ neutral red ( 30 mins.).

3. The vacuolar demixing of the cytoplasm of the rhizoid in Dryopteris cystolepidota C. Christensen. a, b. Dipped in $0.5 \mathrm{~mol}$. $\mathrm{KCl}$-solution (20 mins.), after stained by $0.05 \%$ methylene blue (30 mins.). c, d, e. Dipped in $0.5 \mathrm{~mol}$. $\mathrm{KCl}$-solution ( 20 mins.), after stained by $0.02 \%$ pyronin $(20 \mathrm{mins}$.).

4. The condensation of the cytoplasm of the rhizoid in Dryopteris cystolepidota $\mathrm{C}$. Christensen. a, b. Dipped in $\mathrm{CaCl}_{2}$-solution ( 20 mins.), after stained by $0.05 \%$ methylene blue ( 30 mins.). Dotted portion shows the condensed cytoplasm.

5. The polar staining of the cytoplasm of the rhizoid in Pentarhizidiun japonicum Hayata. Stained by $0.01 \%$ erythrosin ( 20 mins.). Dotted portion shows the stained cytoplasm and the staining of the apical portion is deep.

6. The granular staining of the cytoplasm of the rhizoid in Pentarhizidium japonicum Hayata. Stained by $0.02 \%$ magdara red $(2 \mathrm{hrs}$.).

7. The nonhomogeneous staining of the rhizoid in Pteridium aquilinum kuhn var. latiusculum Tagawa. Stained by $0.005 \%$ fuchsin red (10 mins.). Dotted portion shows the stained cytoplasm.

8. The staining of the cap of the glandular hair in Dryopteris saxifraga $\mathrm{H}$. Ito. Stained by $0.005 \%$ methyl violet (10 mins.). Oblique lines show the stained portion.

9. The drop-like demixing of the cytoplasm in Dryopteris saxifraga $\mathrm{H}$. Ito. Dipped in $0.5 \mathrm{~mol}$. $\mathrm{KCl}$-solution (30 mins.), after stained by $0.005 \%$ methyl violet ( 10 mins.).

10. The vital staining of the prothallial cell membrane drawn schematically in Pteridium aquilinum Kuhn var. latiusculum Tagawa. Stained by $0.05 \%$ thinin (10 mins.). a. $\mathrm{pH} 40$, b. pH 6.4, c. $\mathrm{pH}$ 8.0. 